トピックス

\title{
FIB を用いたナノテク材料のピンポイント解析
}

\author{
上野武夫*，矢口紀恵*，今野 充*，橋本隆仁 ${ }^{* *}$, 小池英巳 ${ }^{* *}$, 大西 毅** \\ *(侏)日立サイエンスシステムズ（テ312-8504＼cjkstart茨城県ひたちなか市市毛 882） \\ **(侏日立ハイテクノロジーズ（テ312-8504＼cjkstart茨城県ひたちなか市市毛 882）
}

\section{Pin-Point Characterization of Nano-Materials Using FIB Technique}

\author{
Takeo KAMINO*, Toshie YAGUCHI*, Mitsuru KONNO*, Takahito HASHIMOTO**, \\ Hidemi KOIKE** and Takeshi OHNISI** \\ ${ }^{*}$ Hitachi Science Systems (882, Ichige, Hitachinaka-shi, Ibaraki 312-8504) \\ ${ }^{* *}$ Hitach High Technologies Co., Ltd. (882, Ichige, Hitachinaka-shi, Ibaraki 312-8504)
}

Key Words : Nano-materials, Pin-point Characterization, FIB Milling, Transmission Electron Microscope

\section{1.はじめに}

ナノテク材料の分野では機能の向上や新機能の発現を目的 とした材料の複合化と構造のち密化が急速に進んでいる。そ のような材料の解析には原子レベルの高い分解能で材料内部 微細構造が直視でき, しかもサブ nm オーダの極小領域の組 成分析が可能な分析電子顕微鏡は不可欠な解析装置となって いる。分析電子顕微鏡を用いた材料解析を正確に行うために は解析目的に合った試料の薄膜化が必要である。試料の作製 には, ダイヤモンドナイフを用いて薄片試料を切り出すウル トラミクロトーム法, 電解液中で試料を薄膜化する電解研磨 法, Arイオンを用いるイオンミリング法など, いろいろな 方法が用いられている。最近, 電子材料をはじめとする先端 材料の分野ではセラミックスと金属，金属と高分子材料など， 性質の大きく異なった材料を組み合わせた複合材料が新機能 材料として開発されている。そのような材料では特に界面の 構造解析や組成解明が重要である。しかし, 従来の試料作製 法ではそのニーズに合った試料の作製が困難な場合が多く なってきている。そのようなニーズの変化を背景に開発され た試料作製法のひとつに集束イオンビーム(Focused Ion Beam：FIB) 加工法がある ${ }^{1)}$ 。FIB 加工法は元々, 半導体分 野の配線修復や断面加工に開発された手法であるが，金属や セラミックスなどの一般材料の薄膜試料作製にも応用できる ことが確かめられて以来，急速にその応用が拡大している。 最近ではほとんどすべての固体材料の薄膜試料作製に応用さ れていると言っても過言ではないほどその普及が進んでいる。 本稿では FIB 加工法の簡単な原理, 特長拈よび FIB 加工技 術と STEM 観察技術を組み合わたピンポイント材料解析法 とその応用について報告する。

\section{FIB 加工法}

FIB 加工装置の鏡体はイオン銃，収束レンズ，走査コイ ル，対物レンズおよび試料室により構成されている。その構
成と構造は極めて走査電子顕微鏡に似ている。走査電子顕微 鏡の電子銃のかわりにイオン銃が, 電子線のかわりにイオン が用いられている。イオン源としては液体 Ga が用いられて いる。これは $\mathrm{Ga}$ は比較的重く, 融点および蒸気圧が低く, しかもエミッ夕金属(通常, W が使われる) との濡れ性がよ いなど, FIB 加工装置のイオン源として適した性質を有し ているためである。FIB 加工装置ではイオンで励起した二 次電子像 (走査イオン顕微鏡像と呼ぶ)を観察することができ る。この観察機能を利用し, 加工前の加工位置設定や, 加工 中の試料の形状変化を詳細に観察することができる。この点 が他の電子顕微鏡試料作製法と異なる点であり, FIB 加工 法がデバイスなどのように構造が微細で評価すべき領域が限 定される材料に不可欠な試料作製法となっている所以である。 また, 試料に照射するイオンビームの電流および直径は任意 に変えることができる。この機能を利用し, 加工段階に合せ て加工条件を設定することができる。通常, 粗加工には大電 流のビームを, 仕上げ加工には小電流のビームを用いる。こ れにより迅速で, しかも損傷の少ない薄膜試料作製が可能と なる。これも他の方法にはない FIB 加工法特有の長所であ る。従来, 機械研磨法とイオンミリング法の組み合わせによ る加工では約二日間を要していた薄膜試料作製が約二時間に 短縮された例もある。

FIB 加工による薄膜試料作製に際しては, まず, 予備加 工, 試料の固定, 加工領域の保護などが必要である。以下に その手順と, FIB を用いたピンポイント加工法およびその 応用例について述べる

\section{1 FIB 加工試料の前処理}

$\mathrm{FIB}$ 加工ビーム径は大きくてもサブ $\mu \mathrm{m}$ 程度であるので 加工速度も他の方法に比べ遅い。したがって迅速に TEM 試 料を作製するためにはFIB 加工前に試料を薄く切り出して おく必要がある。切り出しには通常ダイシングソーや研磨器 が用いられる。FIB 加工で均一に薄膜化できる深さは最大 約 $20 \mu \mathrm{m}$ 程度である。それ以上の深さになると厚さムラや 
FIB リフトアウト法

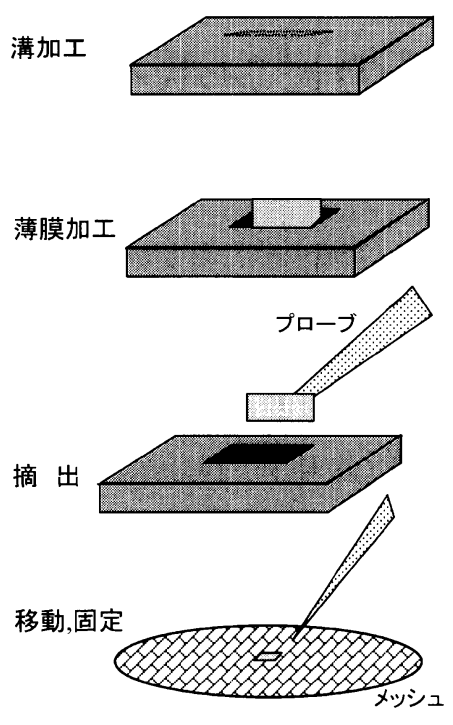

FIB マイクロサンプリング法

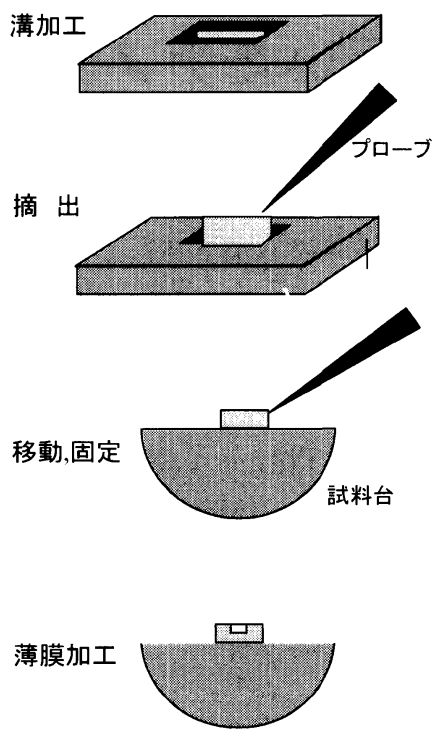

図 1 FIB リフトアウト法とFIB マイクロサンプリング法

削りカスによる污染, イオン損傷などが発生する。したがっ て, 観察個所が試料表面から $20 \mu \mathrm{m}$, またはそれ以上, 深い ところにある場合は観察個所が表面から $2 \sim 10 \mu \mathrm{m}$ 程度の深 さに位置するよう試料表面の研磨が必要である。また，FIB 加工の場合, 試料表面の凹凸が厚さムラの原因になることが 多い。したがって, 試料表面はできるだけ平坦に研磨するこ とが望ましい。試料に帯電が生じた場合, イオンビームが不 安定になり微細加工ができない場合がある。それに備え, 試 料が絶緑材料の場合, 予めカーボンや Pt, Pdなどの金属を コーティングしておくとよい。試料がホルダーにそのまま固 定できない大きさの場合, 切り欠きメッシュと呼ばれる FIB 加工試料専用の試料台に貼り付ける。貼り付けにはマ ニキュアなどを用いる。

FIB 加工では試料表面に損傷が入り易い。この対策とし て試料表面に金属のデポジションを行う。一般に, W, Pt, C などが用いられる。デポジション膜は長さ約 $15 \sim 20 \mu \mathrm{m}$, 幅 約 $2 \sim 3 \mu \mathrm{m}$, 厚さ約 $1 \sim 2 \mu \mathrm{m}$ にわたつて堆積させる。金 属デポジション膜を堆積させる機能はFIB 加工装置に備 わっている。ただし，この金属デポジションには Gaイオン 照射が必要で, 試料表面には $\mathrm{Ga}$ イオン照射による損傷が発 生する。したがって, 試料最表面の微細構造を観察する場合 はカーボン蒸着や金属スパッタなどによる表面保護が必要で ある。

\section{2 FIB 加工}

FIB 加工では粗加工, 中加工, 仕上げ加工と仕上がりに 合せてビーム径を変えながら加工する。粗加工には直径約 $0.5 \mu \mathrm{m}$, 中加工には直径約 $0.1 \mu \mathrm{m}$, 仕上げ加工には直径約 $50 \mathrm{~nm}$ のビームが使われる。

通常厚さ数 $\mu \mathrm{m}$ までは粗加工ビームで, 厚さ $0.5 \mu \mathrm{m}$ まで は中加工ビームで, それ以下は仕上げ加工ビームが用いられ る。Si デバイスのような材料は特に問題にならないが, 弾 性変形する一般的な金属の場合, 薄膜化された領域に周囲の 厚い部分からの応力が集中し薄膜が湾曲することがある。そ
のような場合には薄膜部の一端または両端に切り込みを入れ るとよい。この作業は湾曲する前に行うことが望ましい。試 料を傾けて加工断面を観察すると薄膜化領域の構造を確認で きる。ただし，この観察は試料厚さが数ミクロン以上の場合 は問題ないがそれ以下の厚さではこの観察は避けるべきであ る。肝心の薄膜試料に Gaイオン照射による損傷が導入され る場合がある。どうしても加工個所の確認を行いたい場合は 加工を一旦中断し, 電子顕微鏡を用いた二次電子像または透 過電子像観察を行う。

\section{3 解析個所の摘出 (FIB リフトアゥト法と FIB マイク ロサンプリング法)}

FIB 加工試料は通常, 数 $10 \mu \mathrm{m}$ 程度の薄板に予め機械加 工する。解析個所が限定されず, 機械研磨や切削の容易な材 料ではその方法で特に問題はないが, 電子デバイスなどのよ うにその製造に多大な時間とコストを要する材料ではわずか 数 $\mu \mathrm{m}$ 程度の領域の観察に数 $100 \mathrm{~mm}$ オーダーの広領域を犠 牲にすることはその損失が大きい。また，機械的な切り出し では近接した箇所から複数の薄膜試料を作製すること困難で ある。そのような問題の対策として材料から直接 FIB 加工 により数 $10 \mu \mathrm{m}$ の小さな試料を摘出する方法が最近開発さ れている。FIB リフトアウト法 ${ }^{2), 3}$ およびFIB マイクロサン プリング法(4) 6) である。それらの方法の概要を図 1 に示す。 FIB リフトアウト法は FIB 加工装置内で薄膜加工を行い, その薄膜試料を FIB 加工装置外で摘出し, 観察用メッシュ に載せる方法である。試料は静電気を帯びたガラス棒に付着 させて移動し，カーボン膜などを貼った電子顕微鏡用金属 メッシュ上に落とすため固定場所の細かな調整は困難である が, 加工時間は短く, 特に解析個所を問わない試料の薄膜作 製には適した方法である。FIB マイクロサンプリング法は 厚さ数 $\mu \mathrm{m}$ に力加工した微小試料片を FIB 加工装置内で摘 出し, 別の試料台に固定した後, 引き続き薄膜加工する方法 である。すべての操作を FIB 加工装置内で二次電子像を観 察しながら行うため特定個所を確実に試料作製できる。故障 


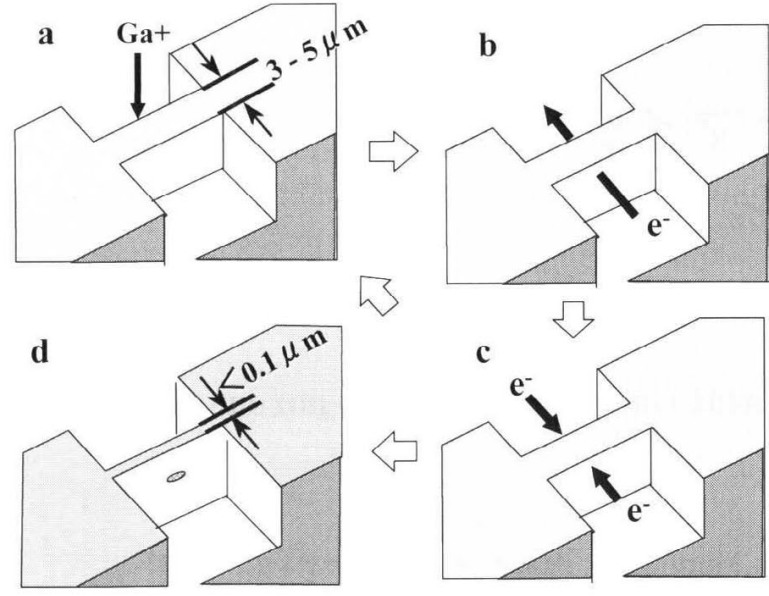

図 2 FIB-TEM システムを用いた三次元構造解析法

解析のように特定領域の構造評洒に適した方法である。

\section{3.ピンポイント解析法}

材料の微細化，複雑化が進むにともない，特定の厚さの試 料から得られる情報だけでは十分な構造解析ができないとい うケースが増えている。その刘策として開発された方法のひ とつに FIB 加工装䈯と透過電子顕微鏡のシステムを用いた 三次元構造解析法がある。透過電子顕微鏡は走查透過電子顕 微鏡像 $(\mathrm{STEM})$ 観察機能および二次電子像 $(\mathrm{SEM})$ 観察機能 を供えたものを用いる。FIB 加工と TEM 観察を交互に行 うことにより材料の微細構造を三次元的に把握しながら正確 に解析個所の薄膜化を行い, ナノ構造解析を行うこと方法で ある。図2にその手順を示す。FIBにより $3 \sim 5 \mu \mathrm{m}$ の厚さ に加工した試料 (a) を STEM 観察(b)および高電圧 SEM 観 察(c)することにより試料内部と断面近傍の構造を三次元的 に把握する。次にそれらの観察で得られた情報をもとに加工 位置と加工量を決め, FIBにより追加工する。以上の操作 を繰り返すことにより，目的個所から正確に薄膜試料を作製 し，解析を行う (d)。この方法では試料内部構造の観察手段 として電子線を用いているため試料への損傷をできるだけ抑 えて正確に解析箇所を探し出すことができる。この加工法で は $0.1 \mu \mathrm{m}$ 以上の加工位置精度が期待できる。

\section{4. 応用例}

図 3 にFIB ピンポイント薄膜作製法で探索，薄膜化した SUS 中の析出物の TEM 像を示す。観察時の試料厚さは約 $0.1 \mu \mathrm{m}$ である。析出物が異なった成分から成る二個の粒子

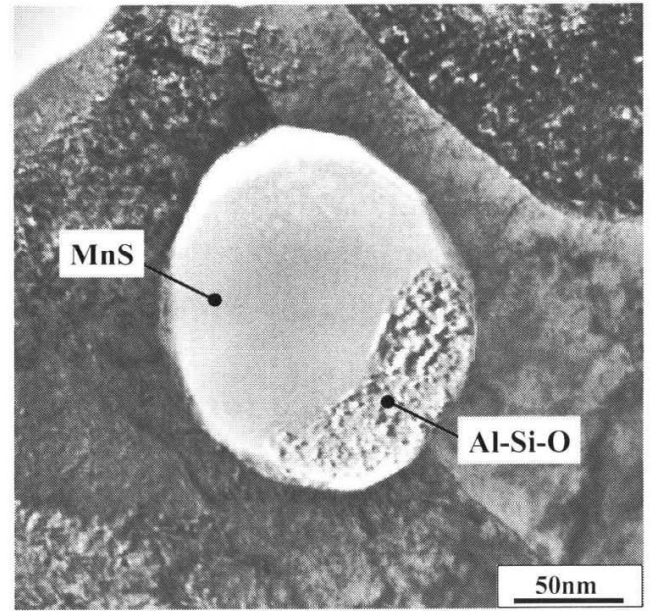

図 3 ピンポイント加工法により探索薄膜加工したSUS 中の析 山物

で構成されていることが分かる。このような試料の場合，母 材の主成分 $(\mathrm{Fe}, \mathrm{Ni}, \mathrm{Cr}$ ) と析出物の主成分 ( $\mathrm{Mn}, \mathrm{S}, \mathrm{Al}, \mathrm{Si}, \mathrm{O})$ の原子番号差による SEM 像, STEM 像のコントラスト差 を利用して析出物を探し出している。

\section{5. まとめ}

以上, FIB 加工法の原理, および透過電子顕微鏡用薄膜 試料の作製法およびFIB と TEM (STEM)を用いたピン ポイントと解析法について述べた。最先端材料分野での TEM 解析の重要性は今後ますます高まることが予想される。 ここに述べた新しい材料解析技術が今後の新材料開発研究に 有効に活用されることを期待したい。

(2002-8-28 受理)

\section{文献}

1 ) M. H. F. Overwijk ; J. Vac. Sci. Technol., B 11, 2021 (1993) 2) L. A. Gianuzzi, J. L. Drown, S. R. Brown, R, E, Irwin and F. A. Stevie ; Mater. Res. Soc. Symp. Proc., 480, 18 (1997)

3 ) L. A. Gianuzzi, J. L. Drown, S. R. Brown, R, E, Irwin and F. A. Stevie ; Micros. Res., Tech., 41, 283 (1998)

4) T. Ohnishi, H. Koike T. Ishitani, S. Tomimatsu, K. Umemura and T. Kamino : Proc. $25^{\text {th }}$ Int. Symp. For Testing and Failure Analysis, p. 449 (1999)

5 ) 梅村他：日本電子顕微鏡学会第 55 回学術講演会予稿集, p. 82 (1999)

6) 矢口他：日本電子显微鏡学会第 56 回学術講演会予稿集, p. 184 (2000) 